\title{
Evaluation of the Neurobehavioural Toxic Effects of Taurine, Glucuronolactone, and Gluconolactone Used in Energy Drinks in Young Rats
}

\author{
Genç Sıçanlarda Enerji İçeceklerinde Kullanılan Taurin, Glukuronolakton \\ ve Glukonolaktonun Nörodavranışsal Etkilerinin Değerlendirilmesi
}

\author{
(D) Revathi BOYINA ${ }^{1 *}$, (D) Sujatha DODOALA2 \\ ${ }^{1}$ MLR Institute of Pharmacy, Department of Pharmacology, Hyderabad, India \\ 2Sri Padmavati Mahila Visvavidyalayam, Institute of Pharmaceutical Technology, Department of Pharmacology, Tirupati, India
}

\begin{abstract}
Objectives: The neurotoxic effects of food additives used in energy drinks have been investigated since the 1900s but safety concerns are rising and reassurance via safety testing in animals is demanded by the public. Rigorous safety testing is performed for dose optimisation and duration of treatment and to detect the methods to assess changes in mood and behaviour. Hence, we studied the neurobehavioral effects of selected food additives used in energy drinks and their combination in rats when consumed in high doses.

Materials and Methods: Young Sprague Dawley rats were divided into six groups. Group 1 was treated with the vehicle, group 2 was treated with $25 \mathrm{mg} / \mathrm{kg}$ p.o. caffeine, group 3 was treated with $5 \mathrm{mg} / \mathrm{kg}$ p.o. glucuronolactone, group 4 was treated with $8 \mathrm{mg} / \mathrm{kg}$ p.o. taurine, group 5 was treated with $84 \mathrm{mg} / \mathrm{kg}$ p.o. gluconolactone, and group 6 was treated with a combination of the three food additives. Neurobehavioral changes were evaluated on days 7, 14, and 21 using behavioural parameters. Neurobehavioral scoring and neurotransmitter estimation in rat brain tissue was performed on day 21.

Results: Significant changes were observed in the neurobehavioral parameters and neurobehavioural scoring in group 4 and group 6 , compared with the control group ( $p$ 0.001). Furthermore, the significant decreases in neurotransmitter levels in the brains of rats that were treated with food additives indicated the neurotoxic effects of these substances.

Conclusion: This study elaborated the neurobehavioral effects of selected food additives, namely glucuronolactone, taurine, and gluconolactone, when administered orally for 21 days in young rats. The highest toxic effects, including alterations in neurotransmitter levels, were observed in animals treated with a combination of food additives at high doses.
\end{abstract}

Key words: Energy drinks, food additives, taurine, glucuronolactone, gluconolactone

ÖZ

Amaç: Enerji içeceklerinde kullanılan gıda katkı maddelerinin nörotoksik etkileri 1900'lardan bu yana incelenmektedir; ancak, güvenlilik endişeleri artmaktadır ve hayvanlarda güvenliliklerinin test edilerek onaylanması halk tarafından talep edilmektedir. Sıkı güvenlilik testleri doz ve uygulama süresi optimizasyonu ve ruh hali ve davranıştaki değişiklikleri belirlemek için yapılmaktadır. Bu nedenle, biz enerji içeceklerinde kullanılan seçilmiş gıda katkı maddelerinin ve kombinasyonlarının sıçanlarda nörodavranışsal etkilerini yüksek dozlarda araştırdık.

Gereç ve Yöntemler: Genç Sprague Dawley sıçanlar altı gruba ayrıldı: Grup 1'e taşıyıcı, grup 2 'ye 25 mg/kg p.o. kafein, grup 3'e 5 mg/kg p.o. glukuronolakton, grup 4'e $8 \mathrm{mg} / \mathrm{kg}$ p.o. taurin, grup 5'e $84 \mathrm{mg} / \mathrm{kg}$ p.o. glukonolakton ve grup 6'ya üç gıda katkı maddesinin karışımı uygulanmıştır. Davranışsal parametreler kullanılarak nörodavranışsal değişiklikler 7, 14 ve 21. günlerde değerlendirilmiştir. Nörodavranışsal skorlama ve sıçan beyin dokusundan nörotransmitter belirlemenmesi 21. günde yapılmıştır.

Bulgular: Kontrol grubuna kıyasla grup 4 ve grup 6'da nörodavranışsal parametreler ve nörodavranışsal skorlamada belirgin değişiklikler gözlenmiștir ( $p<0,001)$. Dahası, gıda katlı maddeleri uygulanan hayvanların beyinlerindeki nörotransmiter düzeylerindeki belirgin düşüşler bu maddelerin nörotoksik etkilerini göstermektedir.

*Correspondence: E-mail: revspharma@gmail.com, Phone: +918985223029 ORCID-ID: orcid.org/0000-0002-8561-724X

Received: 03.06.2019, Accepted: 07.11.2019

๑Turk J Pharm Sci, Published by Galenos Publishing House. 
Sonuç: Bu çalışma 21 gün boyunca oral olarak genç sıçanlara uygulanan seçilmiş gıda katkı maddelerinden glukuronolakton, taurine ve glukunolaktonun nörodavranışsal etkilerini ayrıntılı bir șekilde göstermiștir. Nörotransmitter düzeyleri dahil en fazla toksik etkiler yüksek dozlarda gıda katkı maddelerinin kombinasyonu uygulanan grupta görülmüștür.

Anahtar kelimeler: Enerji içecekleri, gıda katkı maddeleri, taurine, glukuronolakton, glukonolakton

\section{INTRODUCTION}

We are exposed to neurotoxins naively through food products. Today the evaluation of the effects of food additives on behaviour and mood in adults is of great concern. Various regulatory bodies are encouraging scrutiny of the use of food additives rigorously for safety and reassurance. The Food and Drug Administration (FDA) and European Food Safety Authority have been evaluating and supporting risk assessment and safety in the use of appropriate doses of acceptable daily intake (ADI). The food additives used in many products like baby foods, cool drinks, energy drinks, and soft drinks are approved by the FDA after safety evaluation. However, various food additives like antioxidants, stabilisers, sweeteners, thickeners, preservatives, and flavouring agents have effects on behaviour when taken in high doses that are listed under the safety margin. As of 2006 , FDA guidelines on food additives are classified based on level of concern and safety margin into Low concern level I (12-50 $\mathrm{ppb})$, Intermediate concern level II (50-250 ppb), and High concern level III (250-1000 ppb) based on primary toxicological data. The maximum level of additive that has no demonstrable toxic effect, called the "no-observed-adverse-effect level", and ADI are the check parameters for each food additive. Chronic consumption per day more than the ADI leads to toxicity. The risk to human health varies depending upon the type and time of exposure. Specific studies such as for neurotoxicity, immunotoxicity, and allergenicity are rigorously performed repeatedly to ensure the safety of food additives. ${ }^{2}$

Common food additives used in energy drinks like taurine, glucuronolactone, and gluconolactone are considered elevated risk. The daily exposure to taurine, glucuronolactone, and gluconolactone from energy drinks in young generations is higher than the mean daily exposure $(1420 \mathrm{~mL} /$ day of energy drink or 2.6 cans/day). In adults, chronic habitual intake of energy drinks was reported to cause several neurological disorders including migraine, seizures, endocrine disorders, and neuropsychiatric disorders. ${ }^{3}$ Hence, excessive consumption of energy drinks has toxic effects on the nervous system.

The safety of these food additives used in energy drinks was not documented by the Scientific Committee on Food. According to EFSA 2009 data, the stimulatory effect of taurine on the central nervous system was not clearly documented. The major constituents of energy drinks are taurine, glucuronolactone, and gluconolactone. ${ }^{4}$ Based on this background, a research protocol was elaborated to assess systematically possible neurobehavioural toxic effects in animals of individual food additives and the combination of the food additives taurine, glucuronolactone, and gluconolactone used in energy drinks at high doses. The study included an evaluation of neurobehavioural effects, neurobehavioural scoring, and neurotransmitter estimation in the brain tissue of young rats to show possible neurobehavioural effects and ensure the safety level of food additives used in energy drinks, which are listed under the safety margin.

\section{MATERIALS AND METHODS}

\section{Chemicals and reagents}

\section{Chemicals}

Glucuronolactone, gluconolactone, and caffeine (food grade 99.5\%) were procured from Srineelima Labs, Hyderabad, India. Taurine (food grade 99.6\%) was obtained from Nutrija Lifesciences, Nagda, Madhya Pradesh, India. All other chemicals (analytical grade) were from Himedia Pvt Ltd., India.

\section{Reagents}

Hydrochloric acid $[(\mathrm{HCl})$-butanol solution $(0.85 \mathrm{~mL}$ of $37 \% \mathrm{HCl}$ in $1 \mathrm{~L})$ ], $0.4 \mathrm{M} \mathrm{HCl}(3.4 \mathrm{~mL}$ of concentrated $\mathrm{HCl}$ and made up to $100 \mathrm{~mL}$ with water), $0.1 \mathrm{M} \mathrm{HCl}(0.85 \mathrm{~mL}$ of concentrated $\mathrm{HCl}$ made up to $100 \mathrm{~mL}$ with water), $5 \mathrm{M} \mathrm{NaOH}$ ( $20 \mathrm{~g}$ of sodium hydroxide pellets dissolved in distilled water and volume made up to $100 \mathrm{~mL}$ with distilled water), and $10 \mathrm{M}$ acetic acid (57 $\mathrm{mL}$ of glacial acetic acid and made up to $100 \mathrm{~mL}$ with distilled water) were used. Reagents and buffers like sodium acetate buffer (EDTA pH 6.9), heptane, sodium sulphite solution, and O-phthaldialdehyde (OPT) reagent were obtained from Sigma Aldrich, Hyderabad, India.

\section{Equipment}

A morris water maze (MWM), version 5.0, was obtained from Orchid Scientific. A wooden arena with 64 squares was prepared by Wood Works, Hyderabad. A tissue homogeniser $160 \mathrm{~W}$, a refrigerated centrifuge from Gravity Labs, and a spectrofluorometer model, ALT 2380 (wavelength range 200 to 700 ), were also used.

\section{Animals}

Sprague Dawley albino rats of both male and female in equal ratio weighing 150-200 g were obtained from the animal house of MLR Institute of Pharmacy, Hyderabad. The animals were divided into four groups and housed under standard laboratory conditions (temperature $25 \pm 10^{\circ} \mathrm{C}$, relative humidity $55 \pm 5 \%$, and 12.00:12.00 h dark:light cycle) with standard pellet diet and water ad libitum. The experimental procedure was approved by the Institutional Animals Ethics Committee (IAEC) as required by the Committee for the Purpose of Control and Supervision of Experiments on Animals (CPCSEA), MLR Institute of Pharmacy, Hyderabad (CPCSEA/IAEC/PR3/2019).

\section{Experimental protocol}

All the animals were divided into six separate groups and each group consisted of six animals with equal ratios of males and 
females, $3: 3$ ( $n=6,3$ males +3 females). All the doses were calculated based on the human dose available in the literature and were converted to animal dose. ${ }^{3}$ High doses of food additives were administered and the animals were observed for neurotoxic effects. Group I animals served as controls, treated with water administered orally. Group II animals acted as the working standard treated with caffeine $25 \mathrm{mg} / \mathrm{kg}$ p.o. Group III animals were treated with glucuronolactone $5 \mathrm{mg} / \mathrm{kg}$ p.o., group IV animals were treated with taurine $8 \mathrm{mg} / \mathrm{kg}$ p.o., group $V$ animals were treated with gluconolactone $84 \mathrm{mg} / \mathrm{kg} \mathrm{p.o.,} \mathrm{and}$ group VI animals were treated with a combination of the three food additives (glucuronolactone $5 \mathrm{mg} / \mathrm{kg}$ p.o., taurine $8 \mathrm{mg} / \mathrm{kg}$ p.o., and gluconolactone $84 \mathrm{mg} / \mathrm{kg}$ p.o.). All the animals were treated with freshly prepared doses dissolved in water and administered through an oral gauge every day until day 21 .

\section{Assessment of neurobehavioural effects}

Neurobehavioural changes were observed in animals treated with the respective doses for 21 days. On days 7, 14, and 21 the animals were screened for neurobehavioural effects by functional observational battery (FOB) and the Irwin protocol. ${ }^{5}$ These include studies of behavioural alterations, the MWM test, a locomotor activity test, and the Katz protocol as described below.

\section{Behavioural alterations}

Behavioural changes were evaluated by measuring rearing and paw licking behaviour for 5 min. ${ }^{6}$ The observations were noted by three blind observers.

\section{Morris water maze test}

Cognitive changes such as in learning, conditioning, memory, and attention were evaluated by MWM test in rats. ${ }^{7}$ The maze was a round grey tank $(0.45 \mathrm{~m}$ radius, $0.5 \mathrm{~m}$ tall) filled with water $\left(22^{\circ} \mathrm{C}\right)$ to a depth of $0.15 \mathrm{~m}$. An adjustable platform of size $0.06 \mathrm{~m} \times 0.06 \mathrm{~m}$ made of steel was placed $0.01 \mathrm{~m}$ under the water level and $0.13 \mathrm{~m}$ from the edge. Milk $(1 \mathrm{~mL})$ was added to make the water cloudy and thus the platform was hidden. On the edge of the tank the four letters nominated as north $(N)$, south $(S)$, east (E), and west (W) divided the tank into four portions $(N-W, N-E, S-E$, and S-W). On day 1 , the rats were allowed to swim in the tank for 1 min without the hidden platform. Thus, they were trained for swimming in the tank. On day 2 they were trained to identify and move onto the submerged platform for 6 trials per day until day 5. In each trial the rats were released into the tank with their faces pointing towards the water to confirm immersion. The latency from immersion in the tank to escape onto the hidden platform (maximum duration of trial 2 min) was noted. In 2 min, if the animal could not identify the platform it was physically directed to climb by using a glass rod. Then the score of 2 min was noted for these trials. The number of such unsuccessful trials was calculated. For learning and memorising the spatial cues each animal was given an interval of $0.5 \mathrm{~min}$ on climbing onto the platform.

\section{Locomotor activity test}

Locomotor changes such as coordination and equilibrium were assessed by locomotor activity test. This test consists of a square wooden field measuring $0.8 \times 0.8 \times 0.3 \mathrm{~m}$ and the flooring was divided into 64 squares of equal dimensions. Duration of immobility and locomotion in $5 \mathrm{~min}$ for each animal was recorded.

\section{Katz protocol (neurobehavioural scoring) ${ }^{8}$}

Neurobehavioural scores were calculated for the animals after 21 days' treatment with high doses of food additives and they were evaluated for neurobehavioural toxic effects (Table 1). The observations were noted by three blind observers.

\section{Estimation of neurotransmitters}

Preparation of tissue extract ${ }^{9}$

On day 21 the rats were sacrificed, the whole brain was dissected out, and the subcortical region was separated and weighed. The weighed tissue was homogenised in a homogeniser with $5 \mathrm{~mL}$ of $\mathrm{HCl}$ butanol for about $1 \mathrm{~min}$. The homogenised tissue was then centrifuged for $10 \mathrm{~min}$ at $2000 \mathrm{rpm}$. The supernatant layer

\begin{tabular}{|c|c|c|}
\hline & $\begin{array}{l}\text { Neurobehavioural } \\
\text { effect }\end{array}$ & Scores \\
\hline \multirow{2}{*}{$\begin{array}{l}\text { General behavioural deficit } \\
\text { Consciousness }\end{array}$} & Present & 0 \\
\hline & No attempt (coma) & 20 \\
\hline \multirow[t]{2}{*}{ Respiration } & Normal & 0 \\
\hline & Abnormal & 20 \\
\hline \multirow{2}{*}{$\begin{array}{l}\text { Cranial nerve reflexes } \\
\text { Olfactory (sniffing food) }\end{array}$} & Present & 0 \\
\hline & Absent & 4 \\
\hline \multirow{2}{*}{ Vision (follow hand) } & Present & 0 \\
\hline & Absent & 4 \\
\hline \multirow[t]{2}{*}{ Corneal reflex } & Present & 0 \\
\hline & Absent & 4 \\
\hline \multirow{2}{*}{ Whisker (movement) } & Present & 0 \\
\hline & Absent & 4 \\
\hline \multirow{2}{*}{ Hearing (turning to clapped hands) } & Present & 0 \\
\hline & Absent & 4 \\
\hline \multirow{3}{*}{$\begin{array}{l}\text { Motor deficit: } \\
\text { (Leg/tail movement) }\end{array}$} & Normal & 0 \\
\hline & Stiff & 5 \\
\hline & Paralysed & 10 \\
\hline \multirow{2}{*}{$\begin{array}{l}\text { Sensory deficit } \\
\text { Leg/tail (on pinching) }\end{array}$} & Present & 0 \\
\hline & Absent & 10 \\
\hline \multirow{2}{*}{$\begin{array}{l}\text { Coordination: } \\
\text { Beam walking }(1.5 \mathrm{~cm})\end{array}$} & Present & 0 \\
\hline & Absent & 5 \\
\hline \multirow{2}{*}{ Placing test } & Present & 0 \\
\hline & Absent & 5 \\
\hline \multirow{2}{*}{ Righting reflex } & Present & 0 \\
\hline & Absent & 5 \\
\hline \multirow{2}{*}{ Stopping at edge of table } & Present & 0 \\
\hline & Absent & 5 \\
\hline Neurobehavioural toxicity & Total & 100 \\
\hline
\end{tabular}


$(1 \mathrm{~mL})$ was separated and added to a centrifuge tube containing $2.5 \mathrm{~mL}$ of heptane and $0.3 \mathrm{~mL}$ of $0.1 \mathrm{M} \mathrm{HCl}$. After $10 \mathrm{~min}$ of shaking vigorously the tube was centrifuged under identical conditions. Two layers were separated, the supernatant layer (organic layer) was discarded, and the remaining aqueous extract was used to estimate noradrenaline, dopamine, and serotonin. All the steps were carried out at $0^{\circ} \mathrm{C}$. The brain extracts were stored at $-20^{\circ} \mathrm{C}$ until further experimentation.

\section{Estimation of noradrenaline ${ }^{10}$}

First $0.2 \mathrm{~mL}$ of the aqueous layer was taken from tissue extract stored at ice cool temperature after preparation of extract. Then $0.05 \mathrm{~mL}$ of $0.4 \mathrm{M} \mathrm{HCl}$ and $0.1 \mathrm{~mL}$ of EDTA ( $\mathrm{pH}$ 6-9) were added to the aqueous extract accompanied by $0.1 \mathrm{~mL}$ of iodine solution for oxidation. The reaction was stopped after $2 \mathrm{~min}$ by adding $0.1 \mathrm{~mL}$ of $\mathrm{Na}_{2} \mathrm{SO}_{3}$ solution. Next, $0.1 \mathrm{~mL}$ of acetic acid was added after $1.5 \mathrm{~min}$. The solution was heated to $100^{\circ} \mathrm{C}$ for $6 \mathrm{~min}$. The sample was allowed to cool and excitation and emission spectra were noted from the spectrofluorometer. These interpretations were measured at 395-485 nm for noradrenaline.

\section{Estimation of dopamine ${ }^{10}$}

To $0.2 \mathrm{~mL}$ of aqueous phase extract were added $0.5 \mathrm{~mL}$ of $\mathrm{HCl}$ and $1 \mathrm{~mL}$ of EDTA ( $\mathrm{pH}$ 6.9) accompanied by $0.1 \mathrm{~mL}$ of iodine solution for oxidation. The reaction was stopped after 2 min by adding $0.1 \mathrm{~mL}$ of $\mathrm{Na}_{2} \mathrm{SO}_{3}$ solution. Then $0.1 \mathrm{~mL}$ of acetic acid was added after $1.5 \mathrm{~min}$. The solution was heated to $100^{\circ} \mathrm{C}$ for $6 \mathrm{~min}$. The sample was allowed to cool and excitation and emission spectra were noted from the spectrofluorometer. These interpretations were measured at 330-375 nm for dopamine.

\section{Estimation of serotonin ${ }^{10}$}

First, $0.2 \mathrm{~mL}$ of aqueous tissue extract was added with 0.25 $\mathrm{mL}$ of OPT reagent. Then it was heated for $100^{\circ} \mathrm{C}$ for $10 \mathrm{~min}$. After the sample reached ambient temperature, the readings were taken at 360-470 $\mathrm{nm}$ in the spectrofluorometer for the estimation of serotonin.

Tissue blanks for dopamine and noradrenaline were prepared by adding the reagents of the oxidation step in reverse order (sodium sulphite before iodine). For the serotonin tissue blank, $0.25 \mathrm{~mL}$ of concentrated $\mathrm{HCl}$ without OPT was added. Internal standard was prepared by taking $500 \mu \mathrm{g} / \mathrm{mL}$ each of noradrenaline, dopamine, and serotonin prepared in distilled water: $\mathrm{HCl}$ butanol in 1:2 ratio. The concentration of the neurotransmitters expressed in $\mu \mathrm{g}$ per gram wet weight of tissue was calculated by using the formula: ${ }^{11}$

Concentration of unknown $(\mathrm{Cu})=\frac{\text { Sample O.D-Blank OD }}{\text { Standard O.D-Blank OD }} \times \mathrm{Cs}$

Cs: Concentration of standard $(500 \mu \mathrm{g} / \mathrm{mL})$

OD: Optical density

Statistical analysis

Altogether the results were studied using ANOVA followed by Dunnett's multiple comparisons. GraphPad Prism version 7.0, 2019 was the software used for analysis.

\section{RESULTS}

\section{Neurobehavioural changes}

\section{Behavioural alterations}

Alterations in behavioural effects were observed in animals treated with high doses of individual food additives, with successive increases in the behavioural effects with increases in treatment duration on days 7, 14, and 21. Animals treated with taurine and the combination of food additives showed significant increases in rearing and hind paw licking ( $p<0.001)$ compared with the experimental group. Group VI, given the combination of food additives, showed a high significant difference $(p<0.05)$ in behavioural activity compared with the group given caffeine as shown in Figure 1.

\section{Morris water maze test}

Taurine treated animals showed longer escape latency onto the submerged platform in the water maze compared with the controls. With an increase in the duration of treatment the increase in escape latency was significant $(p<0.001)$. Animals treated with the combination of food additives showed significantly ( $p<0.05$ ) longer escape latency on day 21 , indicating altered cognitive effects compared with the caffeine treated animals (Figure 2).

\section{Locomotor activity test}

A significant increase in immobility duration was seen in animals treated with individual food additives and the combination of food additives $(p<0.001)$ and with an increase
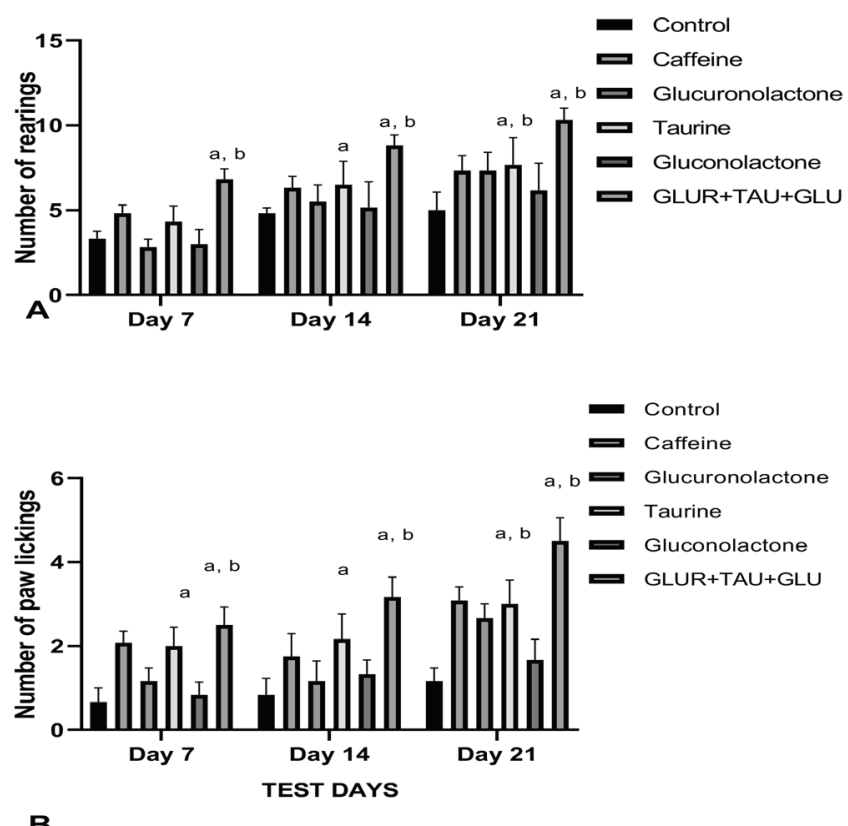

Figure 1. Assessment of neurobehavioural alterations of food additives on exposure to high doses for 7, 14, and 21 days in Sprague Dawley rats by (A) number of rearings and $(B)$ number of paw lickings. Data were represented as mean $\pm \operatorname{SEM}(n=6)$. ${ }^{a} p<0.001$ showed significant differences between the experimental group and the control group. ${ }^{b} p<0.05$ showed significant differences between the food additives treated group and the caffeine treated group

SEM: Standard error of the mean, GLUR: Glucuronolactane, TAU: Taurine, GLU: Glucanolactane 
in duration of treatment compared to the control group when placed in the wooden arena. The combination of food additives caused a significant increase in immobility duration ( $p<0.05$ ), indicating a decrease in locomotion compared to the caffeine treated animals (Figure 3).

\section{Katz protocol of neurobehavioural scoring}

In the Katz protocol animals treated with high doses of individual food additives showed high neurobehavioural scores on day 21. All the experimental groups showed significantly higher ( $p<0.001)$ scores than the control animals (Figure 4). The combination group exhibited the highest neurobehavioural scoring $(p<0.05)$, indicating an increase in neurobehavioural toxic effects compared with the caffeine treated animals.

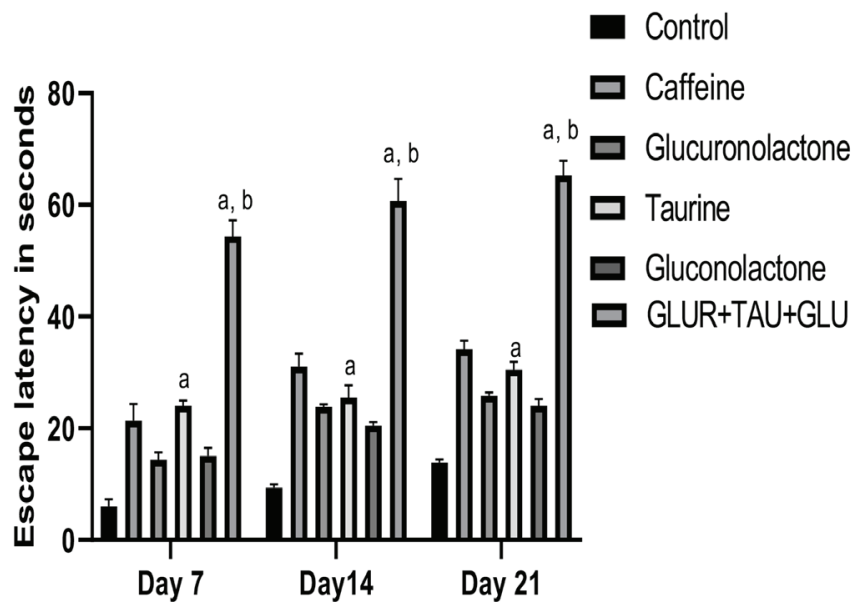

Figure 2. Assessment of neurobehavioural effects of food additives on exposure to high doses for 7,14 , and 21 days in Sprague Dawley rats by escape latency in seconds using the Morris water maze test. Data were represented as mean \pm SEM $(n=6)$. ${ }^{a} p<0.001$ showed significant differences between the experimental group and the control group. ${ }^{b} p<0.05$ showed significant differences between the experimental group and the caffeine treated group

SEM: Standard error of the mean, GLUR: Glucuronolactane, TAU: Taurine, GLU: Glucanolactane

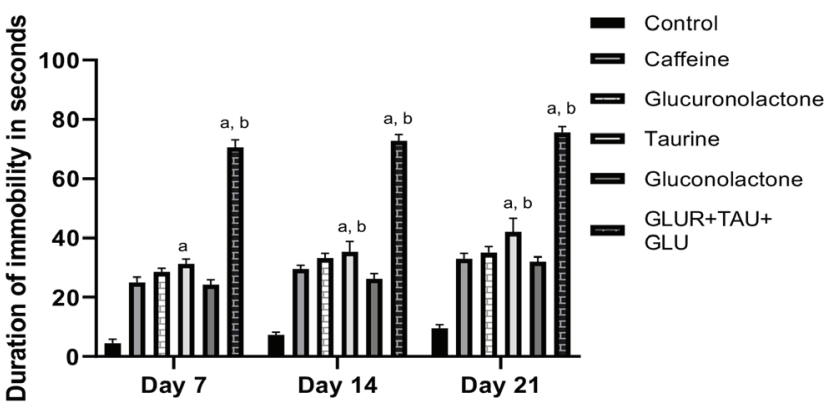

Figure 3. Assessment of neurobehavioural effects of food additives on exposure to high doses for 7, 14, and 21 days in Sprague Dawley rats by duration of immobility using a locomotor activity test. Data were represented as mean \pm SEM $(n=6)$. ${ }^{a} p<0.001$ showed significant differences between the experimental group and the control group. ${ }^{b} p<0.05$ showed significant differences between the food additives treated group and the caffeine treated group

SEM: Standard error of the mean, GLUR: Glucuronolactane, TAU: Taurine, GLU: Glucanolactane

\section{Estimation of neurotransmitters}

On day 21, tissue extract was prepared and neurotransmitters were estimated. The noradrenaline and serotonin levels were pointedly $(p<0.001)$ lower in the taurine and combination of food additives treated animals than in the controls. The combination group animals showed high significance compared with the caffeine treated group ( $p<0.05$ ) (Figures 5 and 6).

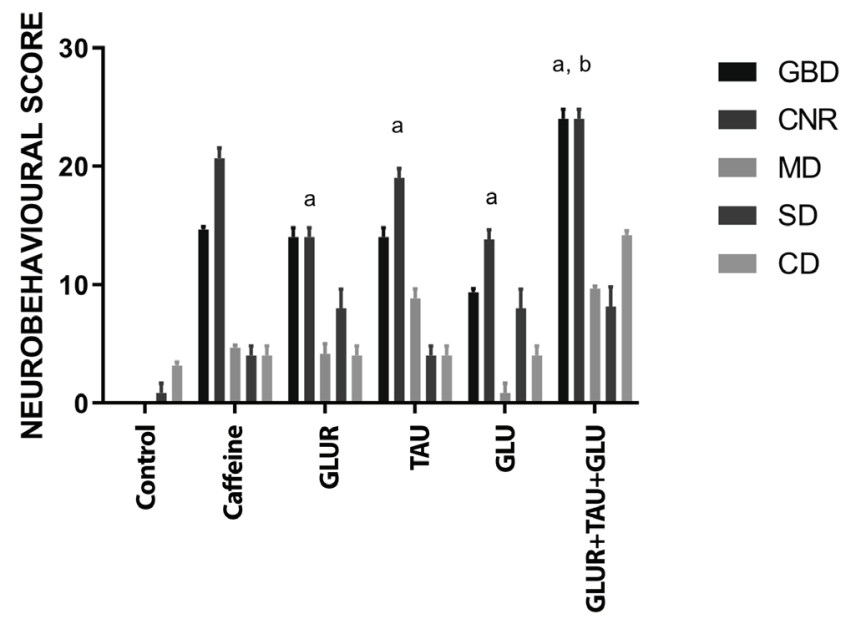

Figure 4. Assessment of food additives on exposure to high doses for 21 days in Sprague Dawley rats for neurobehavioural effects by neurobehavioural scoring using the Katz protocol. Data were represented as mean $\pm \operatorname{SEM}(n=6)$. ${ }^{a} p<0.001$ showed significant differences between the experimental group and the control group. ${ }^{b} p<0.05$ showed significant differences between the experimental group and the caffeine treated group GBD: General behavioural deficits (score 40), CNR: Cranial nerve reflexes (score 20), MD: Motor deficit (score 10), SD: Sensory deficit (score 10, CD: Coordination (score 20), SEM: Standard error of the mean, GLUR: Glucuronolactane, TAU: Taurine, GLU: Glucanolactane

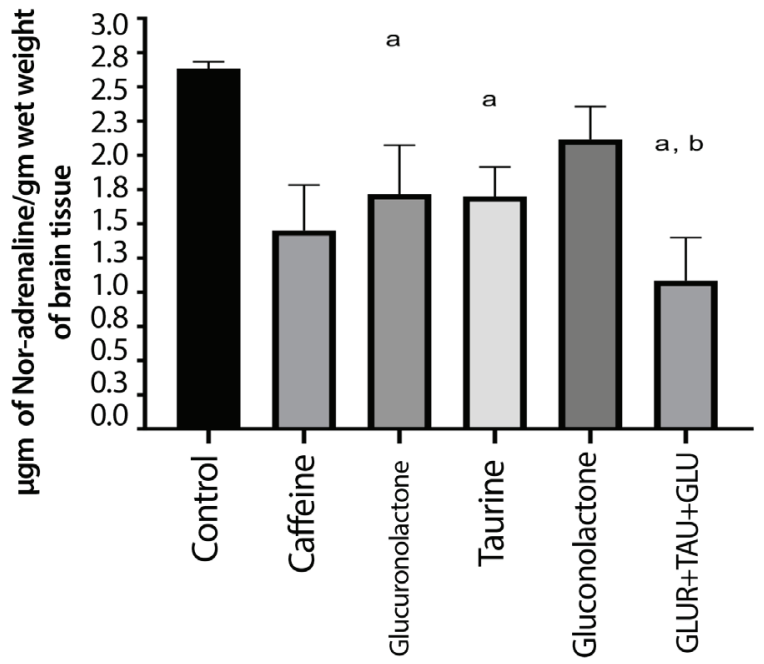

Figure 5. Effect of food additives on Nor-adrenaline levels in whole brain tissue of rats exposed to high doses for 21 days. Data were represented as mean \pm SEM $(n=6)$. ap $<0.001$ showed significant differences between the experimental group and the control group. bp<0.05 showed significant differences between the food additives treated group and the caffeine treated group

SEM: Standard error of the mean, GLUR: Glucuronolactane, TAU: Taurine, GLU: Glucanolactane 


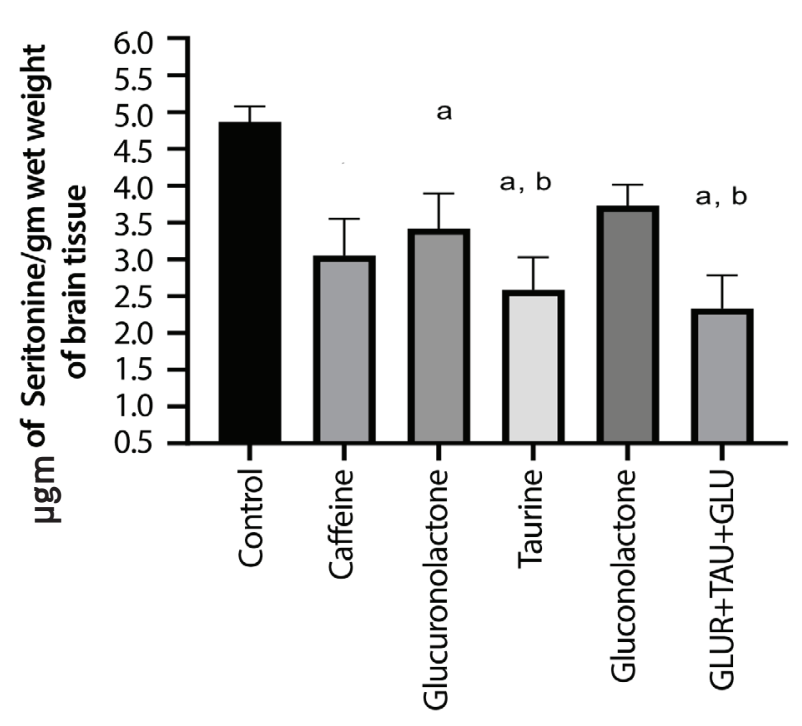

Figure 6. Effect of food additives on serotonin levels in whole brain tissue of rats exposed to high doses for 21 days. Data were represented as mean $\pm \operatorname{SEM}(n=6)$. ${ }^{a} p<0.001$ showed significant differences between the experimental group and the control group. ${ }^{b} p<0.05$ showed significant differences between the food additives treated group and the caffeine treated group

SEM: Standard error of the mean, GLUR: Glucuronolactane, TAU: Taurine, GLU: Glucanolactane

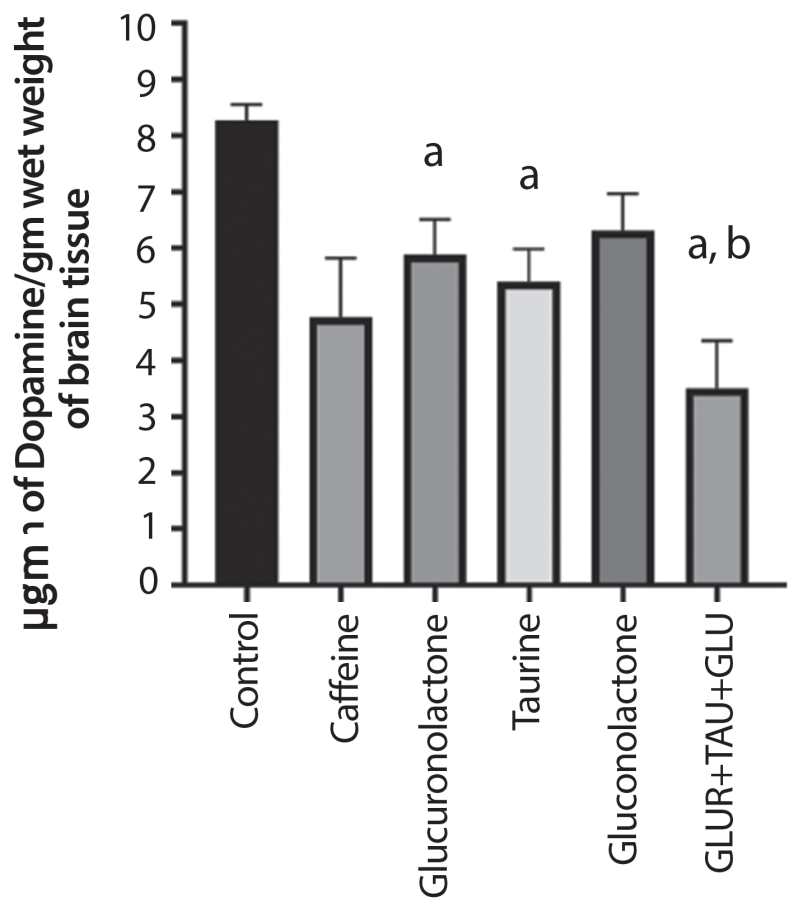

Figure 7. Effect of food additives on dopamine levels in whole brain tissue extract of rats exposed to high doses for 21 days. Data were represented as mean \pm SEM $(n=6)$. ${ }^{a} p<0.001$ showed significant differences between the experimental group and control the group. ${ }^{\mathrm{b}} \mathrm{p}<0.05$ showed significant differences between the food additives treated group and the caffeine treated group

SEM: Standard error of the mean, GLUR: Glucuronolactane, TAU: Taurine, GLU: Glucanolactane
Decreases in dopamine levels were observed in the taurine and combination group animals compared to the control ( $p<0.001)$. The combination animals showed highly significant results when compared with the caffeine treated animals, indicating altered neurotransmission in the brain ( $p<0.05)$ (Figure 7).

\section{DISCUSSION}

The food additives used in energy drinks, when consumed above the acceptable level, were reported to produce toxic effects, as stated by the EFSA. However, the exact ingredients and the dose responsible for toxic effects were not evaluated or documented clearly. ${ }^{4}$ The present research provides evidence for neurobehavioural toxic effects for the selected FDA approved food additives used in energy drinks when consumed above the ADI. The neurobehavioural toxic effects of food additives when administered orally at doses of glucuronolactone $5 \mathrm{mg} /$ $\mathrm{kg}$ p.o., taurine $8 \mathrm{mg} / \mathrm{kg}$ p.o., gluconolactone $84 \mathrm{mg} / \mathrm{kg}$ p.o., and a combination of the three food additives were evaluated and documented over 21 days of treatment in young rats.

Earlier studies suggested that the Irwin protocol (FOB test) explains many parameters and provides a multidimensional method for the explanation of neurobehavioural effects. ${ }^{5}$ Based on the Irwin protocol, the Sprague Dawley rats were treated with food additives and neurobehavioural changes were evaluated using behavioural alterations test, the MWM test, and a locomotor test for clarification of neurobehavioural toxic effects.

Previous literature indicated that behaviour is a measure of the integration of neural function and alteration in behaviour was used to evaluate neurobehavioural toxic effect. ${ }^{5}$ In the present study, alteration in behavioural activity was assessed by considering behavioural parameters like paw licking and rearing behaviours, which were considered indicators of grooming. An increased anxiety level due to any stimulus was reported to change paw licking and rearing behaviour.12 Similar alterations in paw licking and rearing behaviour were caused by taurine and the combination, which clearly indicates the alteration in neuronal functioning with the selected food additives. Previous studies that evaluated cognitive effects in rats using a water maze test reported an increase in duration of escape latencies, indicating a decrease in cognition. ${ }^{13}$ In the present study a significant increase in duration of escape latency to the submerged platform was observed in the taurine and combination groups. The decreased cognition may be due to the decrease in cyclic GMP levels as reported with cognitive impairment and neurobehavioural deficit reported in aluminium toxicity studies. ${ }^{14} \mathrm{~A}$ similar decrease in cGMP levels was reported with taurine in cardiomyocytes..$^{15}$ Our study indicated that neurotoxicity caused by food additives progressively increased with days of exposure from day 7 to day 21. Earlier studies stated that locomotor activity indicates attentiveness. ${ }^{16}$ In the present study, the decrease in locomotor activity indicated by an increase in duration of immobility in the taurine and combination groups affirms that a decrease in attentiveness leads to altered neurological functioning. ${ }^{16}$ 
Previous studies reported that taurine showed dose correlated behavioural changes in rats. Chewing of limbs after treatment with taurine indicated its central pharmacological and neuromodulator effects. ${ }^{17}$ In the present study, the taurine treated group also showed altered behavioural activity, which confirmed its potent neuromodulator effect on neurotransmitters of the brain. In a subacute toxicity study for 14 days in rats, gluconolactone showed mortality, abnormal clinical signs, body-weight changes (on days 1, 2, 3, 7, 10, and 14 ), and gross pathological changes in the brain but was not focused on neurobehavioural symptoms. ${ }^{18}$ Our study for the first time showed changes in behavioural activity in gluconolactone treated animals and may hint at neurotoxicity when consumed higher than the acceptable doses. These changes were high when given in combination with taurine.

Neurological scales/scores for motor, sensory and reflex functions in rats, mice, and dogs were used to detect effects on brain injury. ${ }^{8}$ In the present research work, the Katz protocol of neurobehavioural scores was used considering various parameters like general behavioural deficits, cranial nerve reflexes, motor deficit, sensory deficit, and coordination to evaluate the neuronal damage in animals. High scores for neurobehavioural deficits were observed in animals receiving the food additives in combination, rather than individually. This indicates chances of increases in brain neuronal damage and can be correlated with the decrease in neurotransmitters.

Selected food additives were hypothesised to enhance neurotransmitter activity concentrated in the subcortical regions according to the literature. ${ }^{19}$ Therefore, subcortical regions of whole brain extracts were used to estimate neurotransmitters. Decreases in noradrenaline, serotonin, and dopamine levels indicating neurochemical alterations and neurotoxic effects on subchronic drug administration were suggested previously. ${ }^{20}$ In addition, earlier studies also focused on the participation of serotonin in cognition and memory, and altered serotonergic neurotransmission by toxic substances was reported. ${ }^{21}$ The neurotransmitter modulatory effect of these selected food additives was mentioned. ${ }^{22}$ Corroborating the earlier studies, noradrenaline, serotonin, and dopamine were decreased prominently in the current study. The combination of taurine, gluconolactone, and glucuronolactone caused more noticeable changes in neurotransmitter levels than when given alone, which indicates a risk of more neuronal damage, modulation, and toxicity. These changes support the observed neurobehavioural deficits caused by food additives.

The present study raises concern about the safety of the mentioned food additives at the doses studied considering the aspect of simultaneous consumption of these food additives via energy drinks, although the safety of these additives was established and approved but individually and at a different exposure level. Furthermore, histopathological studies are needed for correlation of neurobehavioural toxic effects.

\section{CONCLUSION}

This study elaborated the neurotoxic effects of glucuronolactone, taurine, and gluconolactone used in energy drinks when consumed above the ADI. It showed significant neurobehavioural toxic effects accompanied by altered neurotransmitter levels in rats treated with a combination of selected food additives. Furthermore, investigation is required to understand the mechanism and interaction between food additives. Appraisal of the developmental neurotoxic effects of these food additives in combination will also be valuable.

Conflicts of interest: No conflict of interest was declared by the authors. The authors alone are responsible for the content and writing of the paper.

\section{REFERENCES}

1. Carocho M, Barreiro MF, Morales P, Ferreira ICFR. Adding molecules to food, pros and cons: A review on synthetic and natural food additives. Compr Rev Food Saf. 2014:4:377-399.

2. Mepham B. Food additives: an ethical evaluation. Br Med Bull. 2011;99:723.

3. Aguilar F, Charrondiere UR, Dusemund B, Galtier P, Gilbert J, Gott DM, Grilli S, Guertler R, Kass GEN, Koenig J, Lambré C, Leblanc JC, Mortensen A, Parent-Massin D, Pratt I, Rietjens IMCM, Stankovic I, Tobback P, Verguieva T, Woutersen RA. The use of taurine and D-glucurono- $\gamma$-lactone as constituents of the so-called "energy" drinks, Scientific opinion of the panel on food additives and nutrient sources added to food, The EFSA J. 2009;935:1-31.

4. New information on ingredients in so-called "energydrinks" opinion of the panel on food additives, flavourings, processing aids, Materials in Contact with Food and Cosmetics of the Norwegian Scienific Committee for Food Safety,Vitenskapskomiteen for mattrygghet (VKM)11 May 2009. ISBN 978-82-8082-327-4. Available from: https:// vkm.no/download/18.2994e95b15cc545071635320/1498417607794/ a8859a2195.pdf

5. Virginia C. Moser, Functional assays for neurotoxicity testing. Toxicol Pathol. 2011;39:36-45.

6. Jintanaporn Wattanathorn, Nongnut Uabundit, Wanchailtarat, SupapornMucimapura, Pisamai Laopatarakasem, Bungorn Sripanidkulchai. Neurotoxicity of Coscinium fenestratum stem, a medicinal plant used in traditional medicine. Food Chem Toxicol. 2006;44:1327-1333.

7. Gasem M. Abu-Taweel, Jamaan S. Ajarem, Mohammad Ahmad, Neurobehavioural toxic effects of perinatal oral exposure to aluminium on the developmental motor reflexes, learning, memory and brain neurotransmitters of mice offspring. Pharmacol Biochem Behav. 2012;101:49-56.

8. Jeon H, Ai J, Sabri M, Tariq A, Shang X, Chen G, Macdonald RL. Neurological and neurobehavioral assessment of experimental subarachnoid hemorrhage. BMC Neuroscience. 2009;10:103.

9. Schlumfjf M, Liechtensteiner W, Langemann $H$, Waser PG, Hefti F. A Fluorometric micro method for the simultaneous determination of serotonin, noradrenaline and dopamine in milligram amounts of brain tissue, Pergamon Press, Printed M Great Britain. Biochem Pharmacol. 1974;23:2337-2446.

10. Habibur Rahman, Eswaraiah MC. Simple spectroscopic Methods for estimating. Brain Neurotransmitters, Antioxidant Enzymes of Laboratory animals like Mice: A review, 2017. Available from: http:// www.pharmatutor.org/articles/simple-spectroscopicmethodestimating-brain-neurotransmitter-antioxidnat-enzymes-lab-animals 
11. Manikkoth S, Deepa B, Sequeira M, Joy AE, Rodrigues R. Assessment of brain dopamine levels to evaluate the role of Tylophora indica ethanolic extract on alcohol induced anxiety in Wistar albino rats. J Young Pharm. 2016;8:91-95.

12. Kalueff $\mathrm{AV}$, Tuohimaa $\mathrm{P}$. The grooming analysis algorithm discriminates between different levels of anxiety in rats: potential utility for neurobehavioural stress research. J Neurosci Methods. 2005;143:169177.

13. Mesaram N, Nagapuri KK, Banala RR, Nalagoni CR, Karnati PR. Quercetin treatment against $\mathrm{NaF}$ induced oxidative stress related neuronal and learning changes in developing rats. Journal of King Saud University Science. 2017;29:221-229.

14. Auti ST, Yogesh A. Kulkarni. Neuroprotective effect of Cardamom oil against Aluminium induced neurotoxicity in rats. Frontiers Neurol. 2019;10:399.

15. Yang Q1, Yang J, Wu G, Feng Y, Lv Q, Lin S, Hu J. Effects of taurine on myocardial cGMP/cAMP ratio, antioxidant ability, and ultrastructure in cardiac hypertrophy rats induced by isoproterenol. Adv Exp Med Biol. 2013;776:217-229.

16. P. Devi Raja Rajeswari, K. Aruna and S. Raja Sankar. The Effect of Biophytum sensitivum Extract Against the Behavioral Changes Induced by 1-Methyl - 4-Phenyl-1,2,3,6-Tetrahydropyridine (MPTP) in mice $J$ Pharm Sci Res. 2016;8:1345-1348.

17. Red Bull Australia Pty Ltd, Submission on Review of Liquor Control Act 1988(WA), 25 February 2012.

18. Safety evaluation of certain food additives. IPCS, Inchem, WHO, Geneva 1999.

19. Miranda Ml. Changes in Neurotransmitter Extracellular Levels during Memory Formation. In: Bermúdez-Rattoni F, editor. Neural Plasticity and Memory: From Genes to Brain Imaging. Boca Raton (FL): CRC Press/Taylor \& Francis; 2007. Chapter 7. Available from: https://www. ncbi.nlm.nih.gov/books/NBK3921/)

20. Takata K, Sheng H, Borel CO, Laskowitz DT, Warner DS, Lombard FW Long-term cognitive dysfunction following experimental subarachnoid hemorrhage: new perspectives. Exp Neurol. 2008;213:334-336.

21. Ahuja M, Bishnoi M, Chopra K. Protective effect of minocycline, a semisynthetic second generation teteracycline against 3-nitropropionic acid (3-NP) induced neurotoxicity. Toxicol. 2008;244:111-122.

22. Gamay, Aly (McLean, VA, US). Neurotransmitter and brain modulating oral delivery system for enhancement of cognitive functions and energy. United States Patent Application number 20180236016. Kind code A1. Publication date 08/23/2018. Filling date 02/14/2018. 